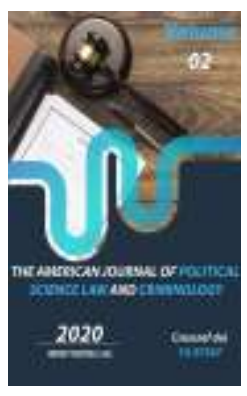

\title{
Issues Of Introduction Of The Probation Institute Instead Of Penalties Not Related To Deprivation Of Liberty
}

\author{
Palvanov Izzat Turaevich \\ Tashkent State University Of Law Senior Teacher Of Specialized Branch, Uzbekistan
}

Journal Website:

http://usajournalshub.c

om/index,php/tajpslc

Copyright: Original

content from this work

may be used under the

terms of the creative

commons attributes

4.o licence.

\section{ABSTRACT}

This article is aimed at covering foreign experience in the introduction of probation and testing institutions as an alternative in the criminal punishment system, and at the same time to investigate the theoretical issues of this criminal legal relationship. In his research, the author emphasized mainly the issues of the use of probation and probation as an alternative instead of the prison sentence, and gave a comparative analysis of the practice of the Republic of Uzbekistan and foreign countries in this field and substantiated conclusions and significant proposals.

\section{KEYWORDS}

Probation service, probation period, penitentiary systems, probation, probation institutions, criminal penalties, probation period, deprivation of Liberty, competent bodies, punishment execution institution, conditional sentence, judicial-investigative bodies, judicial practice.

\section{INTRODUCTION}

In the 40-ies of the XIX century. The conditional sentence was first used by one of the English judges in Birmingham. Then this institution was strengthened by the law "on the testing of the first prisoners" in 1887 year in England, and finally in 1907 year became the law "on the testing of criminals". In continental Europe, conditional condemnation was regulated in 1888 by the Belgian criminal law, and in 1891 in Frantia [1]. The legal nature and content of the Institute for conditional judgment in the legislation of different states are interpreted differently, but nevertheless, statistics show its 
wide distribution and a significant increase in the scope of its application at the moment [2].

The use of conditional conviction means the release of the guilty person from the execution of punishment during a certain probationary period (and in some countries from the criminal responsibility) by presenting to this person certain requirements of conduct, nonexecution means the actual execution of the punishment or the prosecution of the criminal [3].

The probation Institute is close to the criminal law institutes in Russia, mainly on the delay of the probation period and the term of punishment in relation to women with pregnant and young children. Currently, the probationary period is considered the best "alternative" to imprisonment, it provides for a lighter recovery of a convicted person who is not subject to the destructive influence of imprisonment, while retaining the real prospect of correcting a certain category of offenders, eliminating the risk of increasing the number of "prison residents".

It remains only to morally correct those who committed crimes in our country at the present time, to re-educate them in an inseparable partnership with the public without distinction from society large-scale reforms are being carried out in this regard. Therefore, taking into account advanced foreign experience and international standards, with the purpose of early profiling and combating crime, the decree of the president of the Republic of Uzbekistan "on measures for radical improvement of Criminal-executive legislation" has been adopted since 1 January 2019 in our country, the activity of the Probation Service has been established.

"Probation" (lat. Probatio-court) - penological supervision, as a concept of prison, is used in the legal concept for the organization of penological activities (services) to work with convicts who are not related to deprivation of liberty or sentenced to imprisonment. The main tasks of the Probation Service in European countries are the organization, preparation, implementation of alternative sanctions, including monitoring and control [4]. In world practice, the name of the service or department responsible for the trial period may be different.

The trial period is not limited to the issuance of a valve to those who have been taken into the carotene and control over those released, but is applied to all stages of the penological process - from the arrest of the suspect to the selection process until the trial and execution. In recent years, the activities of probation services in many countries have been widely covered, ranging from the rehabilitation of certain prisoners to the reduction of the risk of their involvement in sexual activity with the most vulnerable groups of the population to the prophylactic work.

Probation is a universally recognized International term, which means "trial", a system that increases the efficiency of work on the re-education of convicts who have been sentenced to punishment not related to deprivation of Liberty, including conditional convicts, the realization of their rights.

The first forms of probation service appeared in England in the Middle Ages, the main necessity of which was the fact that the penalties imposed at that time were very strict and cruel.

Modern probation service was established in 1841 year by the US police officer John Augustus. This was caused by an unexpected coincidence. That is, in one of the days the court will send the offender to prison "for drunkenness" and inform him that after 3 weeks the sentence will be read. On the day 
the sentence is read, the offender enters politely, accompanied by the police officer John Augustus. Everyone was surprised that the appearance and temperament of the offender radically changed, and 3 Weeks did not resemble the previous person at all. Later it became known that John Augustus took control of the offender and brought him up morally again. Through this, in the minds of the court and people there appeared an idea that crimes can be picked up by not punishing a person, but by re-educating him.

There is no doubt that the test system will cover all dangerous situations - from the slightest conflict of a person with the law to the fight against relapse-to his coverage. The study of modern European trends shows that a whole chain of works is being created, for example, a new concept related to minors general databases are being created, general principles are being developed (in particular, the concept of permanent support in Canadian programs for working with peers). In general, internships abroad are a social institution aimed at giving vegan to offenders [5].

In the world, the rules relating to conditional condemnation are established by the United Nations in the "minimum standard rules on measures not related to deprivation of Liberty"[6] and in the national legislation of each state. But according to calculations, more than 1 million 200 thousand persons who commit crimes every year are taken into control by the Probation Service [7].

In particular, one-third of those convicted and conditionally imprisoned in the US do not fully comply with these rules, and almost 350 thousand of these individuals are returned to places of imprisonment for violating the rules and committing new crimes [8]. The above indicators create problems with the application of conditional judgment, necessitating the need for legal reinforcement of this measure.

Uzbekistan has joined nearly 100 international human rights treaties, and has provided more than 30 national reports to the relevant UN agencies on compliance with them. The reforms carried out in our country today are all carried out on the basis of the principle for the individual and his interests.

In addition, a wide range of work is being carried out to prevent discrimination of honor and dignity, restriction of legitimate interests.

The first step taken in this regard is that the "Code of correctional labor" adopted in 1970 of the USSR, which violated the dignity and interests of the individual, was changed to the criminal-Executive Code of Uzbekistan in 1997.

According to the Constitution of the Republic of Uzbekistan, human and other inviolable rights of life, land, honor, dignity and other are declared as high values. The next biggest step in this direction was another proof of the recognition of human freedom and life as a high value in Uzbekistan by the abolition of the death penalty in our country since 1 January 2008. At the moment, most countries have been denied the death penalty. Currently, the death penalty is not used in more than 130 countries of the world. Nevertheless, in some developed countries, death penalty is still preserved. In particular, the USA, Belarus, Iran, China They are in the sentence.

In our republic, large-scale reforms are being carried out in the field of effective use of conditional judgment in analyzing the problems of the release of persons who committed crimes from punishment.

In particular, the number of persons convicted on parole for 2015-2019 years amounted to 8 percent of the total number of convicts. However, 4 percent of them violated the terms 
of judgment, their number increased by 6 percent in the period under analysis [9]. To date, the study of the causes and conditions of these cases, the improvement of the control system of convicts, as well as the increase in the effectiveness of established legislative norms of responsibility for violation of the rules of conditional convictions, is of particular importance.

Also, to achieve more effective use of conditional judgment in the future by creating theoretical and legal frameworks for the application of conditional judgment in the moral correction of guilty persons committing a crime.

Decrees of the Prezident of the Republic of Uzbekistan dated October 21, 2016 "On measures to further reform the judicial system, to strengthen the guarantees of reliable protection of the rights and freedoms of citizens", dated February 7, 2017 "On the Strategy of actions for further development of the Republic of Uzbekistan", dated March 2, 2020 "Strategy of Actions for the five priority areas of development of the Republic of Uzbekistan in 2017 - 2021" Science, education and digital economy On the state program for the year of development", as well as decisions dated May 14, 2018 "On measures to radically improve the system of criminal and criminal procedure legislation", November 7, 2018 "On measures to radically improve the criminalexecutive legislation" fulfillment of tasks set by other regulatory legal acts in this area

The priority directions of the strategy of action for 2017-2021 years on the execution of sentences provide for the humanization of the system and, within the framework of the strategy, improve the conditions of storage in the institutions of execution of sentences, the classification system of prisoners improvement is aimed at creating a possibility of resocialization of prisoners[10].

Head of our state Sh. Mirziyoyev appeal to the Oliy Majlis, taking into account the creation of additional measures to ensure the rights of prisoners, it is aimed at further improving the criminal-executive legislation, preventing violations of human rights in all temporary detention and investigation prisons, special receptions, places of administrative detention, provision of punishment-enforcement institutions with video surveillance devices. On these tasks, the state program on the implementation of the strategy of action on five priority directions of development of the Republic of Uzbekistan in 2017-2021 in the "year of implementation of active entrepreneurship, innovative ideas and technologies "has also established specific measures.

Within the framework of the specified tasks, the activities of the punishment execution system are radically improved. In the penitentiary institutions, the dormitories of the convicts, the auxiliary buildings were reconstructed on the basis of today's requirements and fully provided with the necessary equipment.

Particular attention is paid to the adaptation of the sphere of execution of punishment to international standards. The move of the No. 1 investigative prison in Tashkent to a new building was a very big step in this regard.

The determination of the legal status of prisoners is considered to be of political and moral importance. In particular, politically, it refers to the attitude of society and the state to the convict. Because the legal status of the convict is determined by the purpose of punishment, which depends on the socioeconomic structure of the society. Every convicted person who passes the punishment, regardless of what kind of crime he committed 
and the type of punishment, he will not be deprived of his basic rights and obligations and membership in society. Only in the dignity of the law there will be some restrictions, this is manifested in the application of punishment to the convict, in the application of moral and material influence, the convict's forgiveness of the day in worse conditions than citizens is expressed in the restriction of the dignity of the right.

The convicted foreign citizens also have the right to communicate with the diplomatic missions and consular institutions of their countries, while citizens of countries that do not have diplomatic and consular institutions in the Republic of Uzbekistan have the right to communicate with the diplomatic missions of the state, which they undertake to protect their interests.

Based on the analysis of data from the judicial and Probation Service, a conditional sentence was applied to 11,9 percent of total convicted persons in 2015, 5,2 percent in 2019, that is, its application, it was noted that it decreased by almost two times.

He analyzed the contribution of the penalties to be imposed in the application of conditional judgment. In particular, a measure of conditional conviction was applied by the courts when the guilty persons were sentenced to 90-94 per cent of cases, correctional labor in 3-4 per cent of cases, disciplinary punishment in 1-2 per cent of cases or restriction on services.

On the basis of a comparative-legal analysis of the norms of the criminal law of some foreign countries on conditional convictions, there is now a need to apply a conditional sentence even when the restriction of freedom is imposed in accordance with the criminal law of our country.
In accordance with the decision of the president of the Republic of Uzbekistan, on the basis of the Department for control of execution of sentences not related to deprivation of liberty of the main Department of the profile of offenses of the Ministry of internal affairs of the Republic of Uzbekistan and its territorial units, the Probation Service under the main department.

At the same time, the main tasks of the probation departments were defined as:

- Effective organization of activities of the internal affairs bodies on the execution of penalties not related to deprivation of Liberty in cooperation with other state bodies and organizations, as well as public structures;

- To exercise effective control over the conduct of persons who have been conventionally convicted and who have been released from punishment prematurely;

- Comprehensive practical assistance to those under control, as well as through the organization of activities on the social adaptation and employment of minors freed from the punishment institutions, including their professional training;

- $\quad$ To carry out preventive measures to identify and prevent the risk of recommitting a crime under the control, to study their personality in the form of a socio-psychological portrait.

This means that the probation service carries out control over persons who are appointed and conditionally convicted of correctional labor, compulsory public works, restriction of freedom, penalties for deprivation of a certain right. 
At the moment, the Probation Service is very widely used in world practice. If we take foreign experience, the practice of probation was used in relation to 37 percent of those who were conditionally punished (6858) in the army Kazakhstan. As a result, 202 of the total prisoners have repeatedly committed crimes, while 15 of those who have been subjected to probation, that is, 7,4 percent have committed crimes again.

If we summarize briefly through these figures, the role of probation in the Prevention of crimes in the country, as well as in the moral upbringing of convicts, can not be overemphasized.

Thus, the importance of setting up a testing service is that the problems of creating a modern system of social adaptation of former prisoners, profiling and preventing violations are especially relevant today.

\section{REFERENCES}

1. Babina S. A. Osobennosti primeneniya uslovnogo osujdeniya $v$ zarubejnix stranax (naprimere SSHA) // Biznes v zakone. Ekonomiko yuridicheskiy jurna I. № 4. 2010. S. 66.

2. Gabaraev A. SH., Novikov A. V. perspektivi realizatsii instituta probatsii v sovremennoy penitentsiarnoy politiki rossiyskoy federatsii //Sovremennie problemi nauki i obrazovaniya. 2015. № 2(2). Rejim dostupa :http://vvv.skienseedukation.ru/ru/artikle/viev?id=23244 (data obrasheniya:11.10.2016).

3. Nikiforov B. S., Reshetnikov F. M. Sovremennoe amerikanskoe pravo. M., 1990. Rejim dostupa : http://vvv.eye.ski-lib.kom.

4. Tkachevskiy YU. M. Ponyatie uslovnogo osujdeniya // Vestnik
Moskovskogo universiteta. Ser. 11. Pravo. 2003. № 3. S. 36.

5. Xutorskaya N. B. Organizatsiya i deyatel'nost' slujbi probatsii za rubejom // Alternativi tyuremnomu zaklyucheniyu v Rossiyskoy Federatsii: materiali Mejdunar. konferentsii. M., 2001. S.46.

6. Minimal'nie standartnie pravila Organizatsii Ob'edinennix Natsiy $v$ otnoshenii mer, ne svyazannix $\mathrm{s}$ tyuremnim zaklyucheniem [Tokiyskie pravila] prinyatie rezolyutsiey 45/110 OON ot 14 dekabrya 1990 goda: ttps://vvv.un.org/ru/dokuments/dekl_k onv/konventions/tokyo_rules.shtml.

7. https://vvv.google.kom/url?sa=t\&sours $\mathrm{e}=$ veb\&rkt=j\&url=http://vp.unil.ch/spas e/files/2017/03

8. https://vvv.pevtrusts.org/en/researchand-analysis / artikles / 2018 / 10/31/1-in55-us-adults-is-on-probation-orparole.

9. O'zbekiston Respublikasi Oliy sudi va IIV JIEBB huzuridagi Probatsiya xizmatining 2015-2019 yillarga oid statistik ma'lumotlari.

10. O'zbekiston Respublikasi Prezidentining 2017 yil 7 fevraldagi «O'zbekiston Respublikasini yanada rivojlantirish bo'yicha Harakatlar strategiyasi to'g'risida»gi PF-4947sonli Farmoni // O'zbekiston Respublikasi qonun hujjatlari to'plami, 2017 yil, 6-son, 70-modda, 20-son. 